\title{
The implementation of sharia audit process, implication of sharia regulatory and human resource aspects
}

\author{
Dian Rizqiani, ${ }^{1}$ Agung Yulianto ${ }^{2}$ \\ Universitas Negeri Semarang, Indonesia \\ email: rizqianid48@gmail.com
}

\begin{abstract}
Purpose - Audit in Islamic Finance Institute (IFI) is important factor to ensure sharia compliance. This study aims to analyze the factors influencing the process of sharia audit in the IFI.

Method - The population of this research is all of the intern auditor board Sharia Business Unit in Bank Jateng as many as 22 auditors. Sampling technique in this research is census sampling. The method of data collection used is questionnaire. The data analysis used are regression square linear and percentage descriptive analysis. There are three variables in this research which are regulation aspect, sharia resource development, and sharia audit.

Result - The square linear regression analysis used SPSS for Windows Version 20 obtained the equation. The conclusion of this research is regulation toward the influence to the sharia audit, but sharia resource aspect is not. regulation and sharia resourch development toward the influence to the sharia audit.

Implication - The suggestions for the next reseacher is multiply the sample and refference of research and choose Sharia Supervisory Board (SSB) as the respondent for get the relevant result.

Originality - This research empirically examines the factors that influence the implementation of sharia audits at the Central Java Islamic bank. The type of research used is quantitative, because from a number of references found, the topic of sharia auditing that is widely studied is the level of concept with qualitative research type.
\end{abstract}

Keywords: aspect of regulation; aspect of sharia resourh development; sharia audit

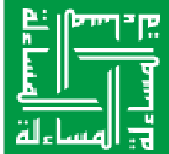

Journal of Islamic Accounting and Finance Research 
Dian Rizqiani, Agung Yulianto

\section{Introduction}

The development of Sharia Financial Institutions (LKS) in Indonesia began with the founding of Bank Muamalat Indonesia in 1992. The existence

JIAFR | 52 of Islamic banking began to draw attention since the events of the monetary crisis that had been experienced by Indonesia in 1998. When many conventional banks experienced bankruptcy, Muamalat banks without the application of the interest system did not affected by the crisis. Ideally, Islamic banks are institutions that must comply with Islamic sharia principles. In practice, the LKS has not fully applied the principles of sharia. Utsmani (2007) in the paper "Sukuk and Their Contemporary Applications" states that found a number of sukuk (sharia obligation certificate) circulating in doubt where there are doubts about the representation of ownership. For example, assets in sukuk can be shared by companies that do not provide actual ownership but only offer sukuk for later repurchase. This is similar to buying back shares, and this is not allowed from a Shariah perspective. Another case is the duplication of sukuk certificates based on a mixture of ijarah, istisna 'and murabaha contracts by banks or Islamic institutions in such a way that they are packaged and sold to sukuk holders who hope to earn some returns.

As one of the LKS, Islamic banks require audits to obtain adequate trust related to sharia compliance. Sharia audits are needed in order to ensure this. Sharia banking needs for sharia audits are based on several regulations related to sharia compliance, which are generally listed in Law No. 21 of 2008. Internal audits are conducted by internal auditors and DPS (Sharia Supervisory Board), while external audits are conducted by KAP (Public Accounting Office) and OJK (Financial Services Authority).

Although Accounting and Auditing Organization of Islamic Finance Institute (AAOIFI) No.1 has issued an Audit Framework Standard for Islamic Financial Institutions, this auditing standard is not a mandatory requirement for LKS in Indonesia. In reality, sharia banking in Indonesia rarely applies PSAK 101-110, because the provisions contained in these standards use pure sharia principles. In Indonesia, sharia banking is given the choice of whether 
to apply pure sharia principles according to PSAK 101-110 or not. The difference is, when banks apply pure murabaha based on PSAK 101, banks may recognize administrative income. However, if the murabahah is not pure, then the technical murabahah agreement is based on wakalah, the amount of funds given to the customer is considered as a fund represented for the supplier who then provides the goods needed by the customer. Another similiar example, namely Musharaka and Mudharabah financing products. Ideally, given the aplication of the pure sharia principles , the musharaka and mudharabah profit sharing is real, meaning that it cannot be determined at the beginning of the contract (akad). However, in general the profit sharing of the two contracts is based on projections. Other Islamic bank products that are legally applied based on impure Sharia principles are deposits. Basically, deposits in Islamic banking are based on wadi'ah contracts. In the principle of pure sharia, profit sharing for deposits should not be determined permanently, meaning that there is a profit sharing ratio and the amount is not constant for every period. According to the staff of the Islamic Banking Department of OJK Central Java, Islamic banking in the city of Semarang in applying revenue sharing for deposit customers, calculates it based on a fixed rate. When profit sharing is not proportionate, banks may give bonuses. This method is still allowed to be applied, what is not allowed is to give promise at the beginning, because it includes interest (usury).

Several studies related to sharia audits in Indonesia gave mixed results. Mardiyah and Mardian (2015) in their study entitled "Sharia Audit Practices in Indonesian Sharia Financial Institutions" stated that sharia audits on the LKS had been running accordingly. However, the opposite statement expressed by Akbar, Mardian, and Anwar (2015) in an article entitled "Unraveling Sharia Audit Problems with Analytic Network Process (ANP)" stated that sharia audits on LKS in Indonesia have not been fully carried out as they should. This was revealed based on cases of violations related to sharia principles that occurred in several LKS in Indonesia.

Bhambra (2007 in Ghani and Rahman, 2015) states that compliance with sharia principles is one of the factors that attract investors to invest a number 
of funds in Islamic banks. Sharia compliance is very important for Islamic financial institutions, especially Islamic banks, because it is a manifestation of the fulfillment of all sharia principles in institutions that have characteristics, integrity and credibility in Islamic banks (Kooskusumawardani and Birton, 2016).

Supervision of sharia compliance is a measure to make sure that sharia principles which are the basic guidelines for sharia bank operation has been implemented appropriately and thoroughly. Supervision and governance for Islamic banking has the obligation to follow sharia principles (sharia compliance). This is what fundamentally distinguishes between Islamic banks and conventional banks (Ilhami, 2009 in Baehaqi, 2014). The need for assurance in the fulfillment of sharia has encouraged the emergence of sharia audit functions. Adequate assurance in sharia compliance is needed through opinions of sharia internal auditors as sharia audit adminstrators (Ghani and Rahman, 2015). In this case, sharia auditors play a crucial role to ensure accountability of financial statements and compliance with sharia aspects. So that stakeholders feel safe investing and funds owned by LKS can certainly be managed according to Islamic law. The audits exists today are part of the conventional financial system which only evaluates economic aspects. However, as scientific and technological developments, the scope of the audit outside the economic aspects began to be highlighted for auditing, such as performance audits, social and environmental audits and sharia audits (Ibrahim, 2008 in Mardian, 2015).

The purpose of this study is to empirically examine the factors that influence the implementation of sharia audits at the Central Java Islamic Bank. This type of research is quantitative. This is the originality of this study because of the few references found, the topic of shariah auditing that is widely studied is the level of concepts with the type of qualitative research. It is hoped that the results of this study will be able to fill the reference gap regarding sharia audits in the future. 
The implementation of sharia audit process ...

\section{Literature Review}

The Grand Theory that underlies this research is sharia enterprise theory and stewardship theory. The concept of sharia enterprise theory includes vertical and horizontal accountability. Vertical accountability is defined as accountability to Allah SWT, and horizontal accountability is divided into two, JIAFR | 55 namely direct stakeholders which include customers and employees, as well as indirect stakeholders covering the community and nature. Sharia enterprise theory has a broader vision on the scope of corporate stakeholders (Triwuyono, 2002 in Mulawarman, 2015). Stewardship theory is a theory that describes the behavior and role of the supervisory board in relation to company management. Glinkowska and Kaczmarek (2015) state that stewardship theory is based on theories of organizational psychology and sociology, and focuses on managerial behavior that is in line with organizational interests. Stewardship theory is in line with the principle of business activities carried out based on sharia principles, namely there is no conflict between managers and shareholders as in the agency theory. Likewise, the relationship between the sharia supervisory board and the LKS management is based on the principle of trust.

Sharia auditing is a way to maintain and ensure the integrity of Islamic financial institutions in carrying out sharia principles (Akbar, et al 2016). The purpose of sharia audits is to ensure the compliance of all bank operations to the sharia principles and rules (Minarni, 2013). Of course this is very important for the sustainability of Islamic bank operations. But the fact is, the Islamic audit itself is also facing various problems and challenges. There are problems that occur in Indonesian sharia audits due to several factors. Akbar, Mardian, and Anwar (2015) suggested that the main problem of sharia audits when analyzed using the Analiytic Network Process (ANP) method is related to aspects of regulation, audit process, and human resources.

\section{Hypothesis Development}

The good implementation of sharia audits, can not be separated from the regulatory aspects in the form of regulations and standards as a guide. 
Stewardship theory which assumes that sharia audit regulators improve employees' compliance with sharia provisions through sharia audit regulations and standards. Sharia audit issues in the regulatory aspects include inadequate sharia audit standards, the absence of sharia audit frameworks, and the lack of encouragement from the government (Akbar, et al, 2016). The effectiveness of the implementation of sharia audits will certainly increase if the regulator sets sharia audit standards and frameworks properly. Shafii, Abidin, \& Salleh (2013, p. 11) states that the pro-active government of sharia audits themselves has been proven to have a significant effect, one of which is by increasing the role of sharia committees with the functioning of the audit. Some Islamic audit indicators related to regulatory aspects include the sharia regulatory audit framework. (Mardiyah and Mardian, 2015).

\section{$H_{1}$ : Regulatory aspect has a positive effect on the implementation of the sharia audit process.}

Meanwhile, The human resource who conduct the Sharia auditing must also have qualifications in the field of sharia and auditing. The problems in the aspect of human resources include the qualifications of sharia auditors which is imbalanced in terms of the accounting and sharia fields, the number of sharia lawmakers - DPS - which are limited and less independent. Shariah enterprise theory implemented in Islamic banks will encourage the management of Islamic banks to apply sharia principles and encourage sharia auditors to apply sharia audits in ensuring the compliance of sharia institutions they supervise. In PBI No. 11/03/2009 concerning Sharia Commercial Bank article 34 requires sharia auditors to at least have competence in the form of knowledge and experience in the field of sharia mu'amalah and knowledge in banking and/or finance in general.

Kasim (2009) revealed a negative correlation between people who controlled accounting and people who controlled sharia, meaning that the higher the people who controlled accounting the lower their mastery of sharia, and vice versa. Both of these fields should ideally be controlled by sharia auditors so that the sharia supervision process carried out can run 
according to standard supervisory procedures. This was also stated by Kasim and Sanusi (2013) that the qualifications and independence of Islamic auditors are important to be strengthened. Akbar (et al) outlines the problems of shariah auditing in the LKS including those related to the qualifications, quantity, and independence of sharia auditors.

$\mathrm{H}_{2}$ : Sharia HR aspects have a positive effect on the implementation of the sharia audit process

\section{Research Methods}

The type of this study is explanatory caussal-comparative research, which is a research to test hypotheses that show a causal relationship between independent variables with the dependent variable. The type of data used is primary data. The object of this study is the Sharia Business Unit (UUS) of BPD Bank Central Java. The unit of analysis in this study is the Internal Auditor Board (DAI) at UUS BPD Bank of Central Java. Data collection techniques used in this study is questionnaire technique that was compiled by researchers based on the underlying theory and adoption of several previous studies.

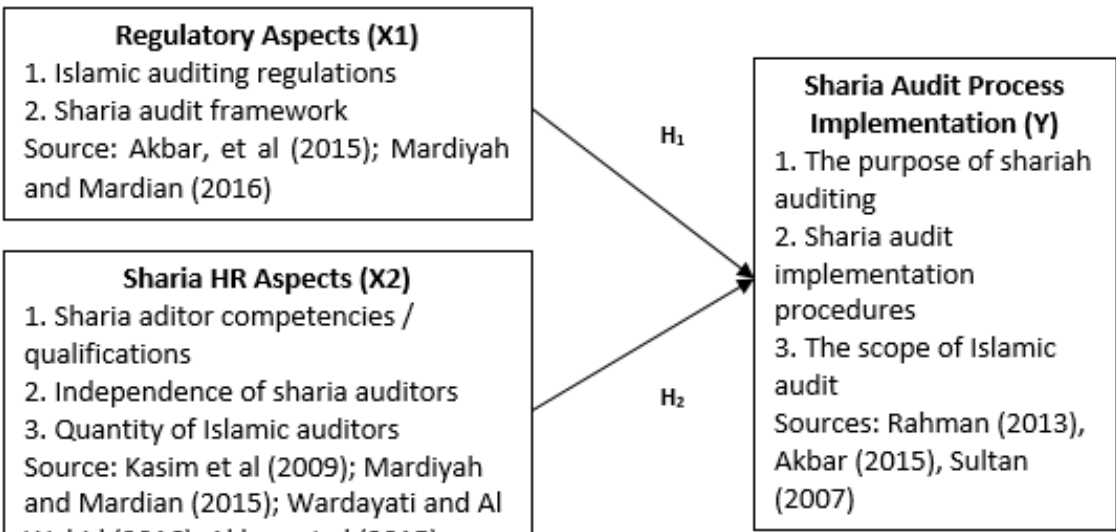

Figure 1. Theoretical Framework 
The population in this study were all members of the Internal Auditor Board (DAI) at UUS BPD Bank Jateng, amounting to 22 people. All members of the internal auditor team at the Bank of Central Java conduct audits for both conventional and sharia branches. In addition, the entire team also has qualifications in the field of sharia. The sampling technique used in this study is the saturation sample technique, which is a sampling technique that makes the entire population a sample because the number is less than 100 . This study uses descriptive analysis tools and multiple regression assisted by the application of SPSS.

Operational definitions and measurement of variables can be seen in the following table 1 :

Table 1. Variable Operationalization

\begin{tabular}{|c|c|c|}
\hline No. & Variable Definition & Measurement Indicators \\
\hline 1 & $\begin{array}{l}\text { Sharia audit is the process of } \\
\text { gathering and evaluating } \\
\text { evidence to determine and report } \\
\text { the level of conformity between } \\
\text { information and criteria } \\
\text { established for the purpose of } \\
\text { shariah compliance. (Abdul } \\
\text { Rahim, 2008) }\end{array}$ & $\begin{array}{l}\text { 1. The purpose of shariah auditing } \\
\text { 2. Sharia audit procedures } \\
\text { 3. Scope of sharia audit. } \\
\text { (Rahman, 2013; Akbar, et al, } \\
\text { 2015; Sultan, 2007) }\end{array}$ \\
\hline 2 & $\begin{array}{l}\text { Regulatory aspects are } \\
\text { regulations compiled by sharia } \\
\text { bank regulators related to sharia } \\
\text { audit implementation standards. } \\
\text { (Akbar, et al; 2015) }\end{array}$ & $\begin{array}{l}\text { 1. Sharia audit regulations. } \\
\text { 2. Sharia audit framework. } \\
\text { (Akbar, et al, 2015; Mardiyah } \\
\text { and Mardian, 2016) }\end{array}$ \\
\hline 3 & $\begin{array}{l}\text { Aspects of Sharia Human } \\
\text { Resources (HR) is a sharia auditor } \\
\text { who has competencies/ } \\
\text { qualifications in the economic } \\
\text { and sharia fields and understands } \\
\text { the LKS concept based on sharia } \\
\text { principles. (Mardiyah and } \\
\text { Mardian, 2016) }\end{array}$ & $\begin{array}{l}\text { 1. Shariah auditor competencies. } \\
\text { 2. Independence of sharia } \\
\text { auditors. } \\
\text { 3. Shariah audit quantity. } \\
\text { (Kasim et al, 2009; Akbar, et al, } \\
\text { 2015; Mardiyah and Mardian, } \\
\text { 2015; Wardayati and Al } \\
\text { Wahid, 2016) }\end{array}$ \\
\hline
\end{tabular}

Source: Formulated from various sources (2018) 
Data collection techniques used in this study were questionnaire techniques. In this study, the questionnaire was distributed to the Internal Auditor Board (DAI) team at the Central Java Bank UUS UUS. The questionnaire was arranged in the form of two parts, namely the respondent's identity and research instruments. The measurement scale for the questionnaire uses a Likert scale consisting of 1 (strongly disagree), 2 (disagree), 3 (neutral), 4 (agree), and 5 (strongly agree).

\section{Results and Discussion}

Kolmogorov-Smirnov test results are $0.738>0.05$. Therefore it can be concluded that the data in this study are normally distributed. The result of the autocorrelation test using Durbin-Watson is 2.087. This value indicates that the data is free from autocorrelation. Based on multicollinearity, the level of correlation between independent variables, namely the variable aspects of regulations and aspects of sharia HR to the implementation of the sharia audit process, is - 638 , or about $63.8 \%$. This correlation is still below $95 \%$, so it can be said that there is no multicollinearity. The results of calculation of the tollerance value in the multicollinearity correlation test were 0.593; This means that there is no dependent variable that has a tolerance value of less than 0.10. The VIF calculation value also shows that there is no independent variable that has a VIF value of more than 10. The VIF value generated from the two independent variables is equal to 1.686 . This means that there is no multicollinearity between independent variables in the regression model.

Multiple regression analysis is used to determine the effect of aspects of sharia regulations and HR on the process of implementing shariah audits at the Central Java Bank UUS. The following results of multiple regression in this study showed in table 2 .

Table 2. The Results of Multiple Regression Analysis

\begin{tabular}{lllrr}
\hline & \multirow{2}{*}{ Model } & & \multicolumn{2}{c}{ Unstandardized Coefficients } \\
& & B & Std. Error \\
\hline \multirow{2}{*}{1} & & (Constant) & 8,373 & 5,841 \\
& & REG & 1,444 & 0,36 \\
& SDM & 0,318 & 0,303 \\
\hline
\end{tabular}


Questionnaires were distributed as many as 25 , but those filled in were 22 questionnaires because 3 members were attending training outside the city for several months. The results of regression analysis using SPSS version 20 produce the equation model $\mathrm{Y}=8.337+1.444 \mathrm{X} 1+0.318 \mathrm{X} 2+\varepsilon$. Constant 8.337 means that if the regulatory aspects and aspects of sharia HR towards the implementation of sharia audit processes are zero, then the implementation of sharia audit processes will be valued at 8.3373 Regression coefficient values of the regulatory aspects of the implementation of sharia audit processes indicate a value of 1.441 . This means that if the variable aspects of sharia HR towards the implementation of the sharia audit process is zero and the constant is zero while the regulatory aspect of the implementation of the sharia audit process is 1,441 , then the sharia audit process will be 1,441. The regression coefficient of the aspects of sharia HR towards the implementation of the sharia audit process showed a value of 0.318 , meaning that if the regulatory aspects of the implementation of the sharia audit process and constants were zero while the aspect of sharia HR on the implementation of the sharia audit process was 0.318 , then the implementation of the sharia audit process would be 0.318 .

$\mathrm{F}$ test (simultaneous) is used to determine the effect of aspects of Islamic regulations and HR simultaneously. Fcount value of 19,046 with a significance level of $0,000<0.05$ means that aspects of sharia regulations and HR simultaneously (jointly) influence the implementation of sharia audit processes. The $t$ test (partial) is used to determine the effect of each dependent variable individually on the independent variable. The partial test results show that the regulatory aspect variable has a significance value of $0,000<0.05$ which means $\mathrm{H} 1$ is accepted, the regulatory aspect variable influences the implementation of the sharia audit process. While the sharia HR aspect variable has a significance value of $0.307>0.05$ meaning H2 is rejected. This means that aspects of sharia HR aspects do not affect the implementation of the sharia audit process.

The simultaneous determination coefficient (R2) is used to measure how far the model's ability to explain the variation of the dependent variable 
(Ghozali, 2011). The coefficient of determination is between zero and one. If the coefficient of determination is small, it means that the ability of the independent variable in explaining the dependent variable is very limited. The closer to one, the ability of independent variables in explaining the dependent variable is getting stronger. The simultaneous determination coefficient test (R2) in this study produced a correlation coefficient (R) of 0.667 , this means that there was a $66.7 \%$ relationship between the aspects of regulation and aspects of sharia $\mathrm{HR}$ on the implementation of the sharia audit process. While the remaining $33.3 \%$ is explained by other factors beyond the variable aspects of the regulations and aspects of sharia HR on the implementation of the sharia audit process. So, it can be concluded that the relationship between aspects of regulations and aspects of sharia HR affects individually on the implementation of sharia audit processes.

\section{Effect of Regulatory Aspects on the Implementation of Sharia Audit Processes}

Based on the results of this study partially known, the variable aspect of regulation (X1) influences the process of implementing shariah audits (Y). This is indicated by the obtained tcount of 4.015 with a significance of 0.001 . Because the significance obtained from these variables is less than 0.05 , it indicates that the regulatory aspect has a positive and significant relationship to the sharia audit process. The results of hypothesis testing (H1) have proven that there are effects of regulatory aspects on the process of implementing shariah audits in the Central Java Bank.

Table 3. The Summary of Hypotheses Testing Results

\begin{tabular}{|c|c|c|c|}
\hline No & Hipotheses & Statement & Result \\
\hline 1 & $\mathrm{H}_{1}$ & $\begin{array}{l}\text { Regulatory Aspects have a positive and } \\
\text { significant effect on the Implementation of } \\
\text { the Sharia Audit Process }\end{array}$ & Accepted \\
\hline 2 & $\mathrm{H}_{2}$ & $\begin{array}{l}\text { The aspects of sharia HR have a positive } \\
\text { and significant effect on the } \\
\text { implementation of the Sharia Audit } \\
\text { Process }\end{array}$ & Rejected \\
\hline
\end{tabular}

Source: Processed primary data 2018 
Hypothesis one (H1) states that the regulatory aspect positively influencing the implementation of the sharia audit process is accepted. Examination of variable aspects of the regulatory aspects of the implementation of the sharia audit process shows that with the implementation of the regulatory aspects of the regulations relating to the application of the audit process in Islamic financial institutions.

The first hypothesis is accepted according to the stewardship theory. The theory illustrates the relationship between organizational success and owner satisfaction. Because stewards are more concerned with shared interests and the achievement of organizational goals, which are based on consideration of rationality, stewards are more likely to cooperate than to oppose. The implication in this research is that the existence of regulators who compile regulations related to sharia audits has an effect on the implementation of sharia audit processes. In this case the regulator focuses on policies related to Islamic auditing. The Government of Indonesia which has the authority to draw up regulations for Sharia Financial Institutions (LKS) includes the National Sharia Board (DSN) and the Financial Services Authority (OJK). It is suggested that DSN and OJK develop regulations, frameworks and standards that can be used as guidelines for sharia auditors and can improve employees' compliance with sharia principles.

This research is in line with an article written by Besar, et al (2009) entitled The Practice of Shariah Review as Undertaken by the Islamic Bank Sector in Malaysia. In the article stated that good regulation and clear standardization can improve the development of Islamic banking.

\section{The Influence of Sharia Human Resources (HR) on the Implementation of the Sharia Audit Process}

Based on the results of the study sharia HR aspects variable (X2) have no effect on the the implementation of sharia audit process $(\mathrm{Y})$. It was indcated by the tcount of 1.049 with a significance of 0.307 . Since the significance obtained from the three variables is less than 0.05 , it shows that the aspects of Sharia HR does not affect the process of sharia audit. The results of hypothesis 
testing (H2) have proven that there is no influence of the aspects of sharia HR on the process of sharia auditing at the Central Java Regional Bank UUS.

Hypothesis 2 (H2) states that sharia Human Resources (HR) affect the implementation of sharia audit processes. Based on the results of the $t$ test of Human Resources (HR) sharia effect on the implementation of the sharia JIAFR $\mid 63$ audit process has a significance value of 0.307 . This value is very far above 0.05 which means that $\mathrm{H} 0$ is accepted and $\mathrm{H} 2$ is rejected. This means that the variable Human Resources (HR) sharia does not affect the implementation of the sharia audit process.

This research is not in line with sharia enterprise theory, where the theory states that the application of sharia enterprise will encourage shariah auditors to carry out shariah audits. The results of this study support research conducted by Kasim (2009), that a sharia auditor must have qualifications in finance and sharia (fiqh muamalah). Competent sharia HR will encourage the implementation of sharia audit processes. In reality, none of the members of the Internal Auditor Board (DAI) at Central Java Bank have Islamic educational background. They get sharia knowledge only through training from the Bank of Central Java. So that understanding of the field of sharia is less profound. In addition, most of the Internal Auditor Board (DAI) in Central Java Bank also has non-financial education background.

Based on descriptive analysis shows that sharia HR is classified in the category of "medium", but sharia HR cannot improve the implementation of sharia audit processes. Islamic HR competencies in Central Java Bank BPD UUS are less in accordance with the competency standards of Islamic auditors when viewed from an educational background. This is influenced by several things including, namely, in the Islamic business unit (UUS), the same internal auditor between conventional branches and sharia branches, sharia audit training to the Internal Auditor Board (DAI) is given globally and not periodically. In addition, there is no auditor team that is specifically responsible for auditing the Central Java Bank UUS. All DAI members will take turns taking the sharia branch auditor team. Indicators of sharia auditor independence on sharia HR variables are classified in the "good" category. 
Based on research conducted by Kasim (2009) states that Islamic auditing can be fully carried out if the auditor is independent. But in this study good independence is not accompanied by good qualifications as well, so it can be concluded that sharia human resources who are able to support the implementation of sharia audits are auditors who are competent in sharia and finance, and must be an independent auditor.

\section{Conclusion}

The conclusion of this study is that the regulatory aspects have a positive and significant effect on the implementation of the sharia audit process at the Central Java Bank UUS, with a Tcount value of 4.015 and a significance of 0.001 . The aspect of sharia HR does not affect the implementation of the sharia audit process at the Central Java Bank UUS. This variable has a t-count value of 1.049 and a significance of 0.307 . Regulatory aspects and Sharia HR simultaneously have a positive and significant effect simultaneously on the implementation of sharia audit processes at the Central Java Bank UUS, $66.7 \%$ and the rest $33.3 \%$ affected by other variables not examined in this study. Suggestions for further researchers to increase the sample of research references, as well as making the Sharia Supervisory Board (DPS) as respondents in order to obtain more relevant results.

\section{References}

AAOIFI. (2003). Accounting, Auditing and Governance Standards for Islamic Financial Institutions, Bahrain: AAOIFI.

Akbar, T., dkk. (2015). Mengurai Permasalahan Audit Syariah Dengan Analytic Network Process (ANP).Jurnal Akuntansi dan Keuangan Islam, 2(2), 101-123.

Antonio, M. S. (2001). Bank Syariah: Dari Teori ke Praktik, Jakarta: Gema Insani.

Arens, et al. (2006). Auditing dan Jasa Asurance: Pendekatan Terintegrasi Jilid 1, Jakarta: Erlangga. 
Baehaqi, A. (2014). Usulan Model Sistem Pengawasan Syariah pada Perbankan Syariah Di indonesia, Jurnal Dinamika Akuntansi dan Bisnis, 1(2), 119-133.

Besar, M. H. A. H., et al. (2009). The Practice of Shariah Review as Undertaken by Islamic Banking Sector in Malaysia, International Review of Business Research Papers, 5(1), 294-306.

DSN-MUI. 2017. Fatwa-fatwa DSN-MUI. https://dsnmui.or.id.

Ghani ,N. L. A., \& Abdul, R. A. R. (2015). An Analysis of Shari'ah Audit Practices in Islamic Banks in Malaysia (Analisis Amalan Audit Shari'ah di BankBank Islam di Malaysia), Jurnal Pengurusan 43, 107-118.

Ghozali, I. (2013). Aplikasi Analisis Multivariate dengan Program IBM SPSS 21, Semarang: Badan Penerbit Universitas Diponegoro.

Glinkowska, B., \& Boguslaw, K. (2015). Classical and Modern Concepts of Corporate Governance (Stewardship Theory and Agency Theory), Journal of Management, 19(2), 84-92.

Hidayah, N. N. (2014). Religious Compliance In Islamic Financial Institutions. Thesis of Aston University.

Ibrahim, A. A. S. (2012). Manajemen Syariah: Sebuah Kajian Historis dan Kontemporer, Jakarta: Rajawali Press.

Junusi, R. E. (2012). Implementasi Shariah Governance Serta Implikasinya Terhadap Reputasi dan Kepercayaan Bank Syariah, Al-Tahrir, 12(1), 87-111.

Karim, R. A. A. (1990). The Independence of Religious and External Auditors: The Case of Islamic Banks, Accounting, Auditing \& Accountability Journal.

Kasim, Nawal, et al. (2013). Assessing The Current Practice of Auditing in Islamic Financial Institutions in Malaysia and Indonesia, International Journal of Trade, Economics and Finance, 4(6).

Kasim, N. B., et al. (2009). Shariah Auditing in Islamic Financial Institutions: Exploring the Gap Between the "Desired" and the "Actual", Global Economy \& Finance Journal, 2(2), 127-137.

Laporan Pelaksanaan Tata Kelola Bank Jateng Tahun 2016. (2016). PT. Badan Pembangunan Daerah Jawa Tengah dan Unit Usaha Syariah. 
Dian Rizqiani, Agung Yulianto

Lewaru, T. S. (2015). Permasalahan Agency Theory Pada Perbankan Syari'ah, Jurnal Ekonomi, 9(1).

Mardian, S. (2013). Auditor Syariah: Lulusan Syariah atau Lulusan Akuntansi, Kordinat Jurnal Komunikasi Antar Perguruan Tinggi Agama Islam

JIAFR | 66 Swasta, 8(1), 179-198.

Mardian, S. (2015). Tingkat Kepatuhan Syariah Di Lembaga Keuangan Syariah, Jurnal Akuntansi dan Keuangan Islam, 3(1), 57-68.

Mardiyah, Q., \& Sepky, M. (2015). Praktik Audit Syariah Di Lembaga Keuangan Syariah Indonesia., AKUNTABILITAS, 8(1), 1-17.

Minarni, (2013). Konsep Pengawasan, Kerangka Audit Syariah, dan Tata Kelola Lembaga Keuangan Syariah, Jurnal Ekonomi Islam La Riba, 7(1).

Mulawarman, A. D. (2015). Akuntansi Syariah: Teori, Konsep dan Laporan Keuangan. E-book.

Otoritas Jasa Keuangan. (2016). Statistik Perbankan Syariah Desember 2016.

Perkembangan dan Prospek Perbankan Syariah Indonesia: Tantangan Dalam Menyongsong MEA 2015, milad k\IAEI.

Perwataatmadja, K. A., \& Hendri, T. (2007). Bank Syariah: Teori, Praktik, dan Peranannya, Jakarta: Celestial Pulishing.

Raharjo, E. (2007). Teori Agensi Dan Teori Stewarship Dalam Perspektif Akuntansi, Jurnal Fokus Ekonomi, 2(1), 37-46.

Rahim, A. A. R. (2011). Enhancing The Integrity of Islamic Financial Institutions In Malaysia: The Case For The Shari'ah Audit Framework, ISRA International Journal of Islamic Finance, 3(1), 135-147.

Rahman, A. R. A. (2011). Shari'ah Audit: A Comparative Perspective, International Islamic University Malaysia (IIUM) \& Research Fellow of ISRA.

Shafii, Z., et al. (2010). Management of Shariah Non-Compliance Audit Risk in the Islamic Financial. Institutions via the Development of Shariah Compliance Audit Framework and Shariah Audit Programme. Kyoto Bulletin of Islamic Area Studies, 3(2), 3-16.

Umam, K. (2016). Perbankan Syariah: Dasar-Dasar dan Dinamika Perkembangannya di Indonesia, Jakarta: PT. Raja Grafindo Persada.

Undang-Undang Nomor 21 Tahun 2008 tentang Perbankan Syariah. 
Usmani, M. T. (2007). Sukuk and their Contemporary Applications. Paper AAOIFI.

Yazkhiruni, Y., \& Nurmazilah, M. (2012). The role of internal auditing in ensuring governance in Islamic Financial Institutions (IFI), Proceedings 3rd International Conference on Business and Economic Research (3rd ICBER 2012), Bandung, Indonesia.

Wahyudin, A. (2015). Metodologi Penelitian: Penelitian Bisnis dan Pendidikan, Semarang: Unnes Press.

Wirdyaningsih, dkk. (2005). Bank dan Asuransi Islam di Indonesia, Jakarta: Kencana Perdana Media. 
JIAFR | 68 